\title{
Üreticilerin Biyolojik ve Biyoteknik Mücadele Uygulamalarına Bakışı ve Çevre Duyarlılıklarının Belirlenmesi
}

\author{
Betül SAYIN ${ }^{\mathscr{9}}$, Alamettin BAYAV², Tuba BEŞEN³ ${ }^{3}$, Dilek KARAMÜRSEL44 Mehmet Ali ÇELIKYURT 5 \\ Meltem EMRE6 ${ }^{6}$ Musa KUZGUN7, Şerife Gülden YILMAZ8, Selda ARSLAN ${ }^{9}$ \\ 1,3,5,7,8Batı Akdeniz Tarımsal Araştırma Enstitüsü, Antalya, ${ }^{2,4}$ Meyvecilik Araştırma Enstitüsü, Isparta, ${ }^{6}$ İzmir İl Tarım ve Orman \\ Müdürlüğü, İzmir, ${ }^{9}$ Tarla Bitkileri Merkez Araștırma Enstitüsü, Ankara \\ ${ }^{1}$ https://orcid.org/0000 00020007 1955, ${ }^{2}$ https://orcid.org/0000 00028093 2988, ${ }^{3}$ https://orcid.org/0000 00019777 793X, \\ ${ }^{4} \mathrm{https}: / /$ orcid.org/0000-0001-7920-1136, ${ }^{5} \mathrm{https}: / / o r c i d . o r g / 0000-0002-7563-7757,{ }^{6} \mathrm{https}: / / o r c i d . o r g / 0000-0003-1141-5888$, \\ ${ }^{7}$ https://orcid.org/0000 00033594 8259, ${ }^{8}$ https://orcid.org/0000 00021888 2588, ${ }^{9} \mathrm{https}: / /$ orcid.org/0000-0002-2387-9447 \\ $\bowtie$ : betulsayin@gmail.com
}

\section{ÖZET}

$\mathrm{Bu}$ araștırma ile biyolojik ve biyoteknik (B/BT) mücadele yöntemlerini uygulayan ve uygulamayan işletmelerden oluşan iki üretici grubu hakkında tanımlayıcı istatistikler elde etmek, sahada biyolojik/biyoteknik mücadele uygulamaları ve üreticilerin konu hakkındaki düşüncelerini öğrenmek ve çevre duyarlılığı açısından gruplar arasında anlamlı farklılıklar olup olmadığını tespit etmek amaçlanmıştır. Araştırma alanı olarak seçilen illerde tabakalı örnekleme yoluyla seçilen 108 üretici ve yine aynı yörede benzer ürün deseni ve tarımsal işletme karakteristiklerine sahip, ancak biyolojik ve biyoteknik mücadele materyallerini kullanmayan 108 üretici olmak üzere toplam 216 üretici ile anket yapılmıştır. Turunçgil ve örtü altı sebze yetiştiriciliğinde iki grup arasında kimyasal ilaçlama sayısı ortalamaları arasında anlamlı düzeyde bir farklılık bulunmuştur. Üreticilerin biyolojik/biyoteknik mücadele yöntemlerini benimsemelerinde uygulama kolaylığının etkili olduğu anlaşılmış, bu mücadele yöntemini kullanma nedenleri sıralamasında insan sağlığı seçeneği ön plana çıkmıştır. Biyolojik/biyoteknik mücadele yöntemlerinin, maliyetleri azaltma, farklı fiyattan ürün satma veya pazarlama kolaylığı sağlama bakımından bir avantaj oluşturmadığı tespit edilmiştir. $\mathrm{Bu}$ yöntemlerin yaygınlaştırılması için üreticiler bilgilendirilmeye ve maddi olarak desteklenmeye devam edilmeli, bunun yanında tüketicileri de bu yöntemlerle üretilmiş ürünleri tüketmeye teşvik edecek bilgilendirme çalışmaları yapılmalıdır. Büyük bölümü ithal edilen B/BT mücadele materyallerinin yüksek maliyetleri üreticileri bu uygulamalardan uzaklaştırmakta, yöntemlerin uygulanması sırasında yaşanan gecikmelerin de ithalat sürecinden kaynaklandığı anlaşılmaktadır. Bu nedenle yerli B/BT materyallerinin üretimi için gerekli alt yapı ve girişimler de desteklenmelidir.

\section{Araştırma Makalesi}

Makale Tarihçesi

Geliş Tarihi : 31.07 .2019

Kabul Tarihi : 28.11 .2019

Anahtar Kelimeler
Entegre zararlı yönetimi
Çevre dostu üretim
yöntemleri
Çevresel duyarlılık

Producers' Perspective on Biological and Biotechnical Control and Determining Environmental Attitudes

\section{ABSTRACT}

The aim of this research was to obtain descriptive information about two producer groups consisting of agricultural holdings applying and not applying biological and biotechnical (B/BT) control methods in in the research field, to determine the B/BT control practices applied in the field, to know the opinions of producers about B/BT applications, whether there are significant differences between the groups in terms of environmental sensitivity. In this study, a total of 216 producers were selected by using stratified sampling, 108 producers using B/BT control materials, and 108 producers in the same region with similar product pattern and agricultural holdings characteristics but not using B/BT control materials. A significant difference was found between the mean numbers of chemical

Research Article
$\begin{array}{ll}\text { Article History } \\ \text { Received } \quad: 31.07 .2019 \\ \text { Accepted } \quad: 28.11 .2019\end{array}$

Keywords
Integrated pest management
Environmentally friendly
production methods
Environmental sensitiveness


application between these two groups. It has been found that ease of application was effective in the adoption of B/BT control methods by producers. It was determined that human health option comes into prominence in the ranking of reasons for using B/BT control method. It has been found that $\mathrm{B} / \mathrm{BT}$ control methods were not an advantage in terms of reducing costs, selling products at different prices or providing ease of marketing. In order to spread these methods, producers should continue to be informed and financially supported. In addition, information should be provided to encourage consumers to consume these products. Importing B / BT control materials leads to increased costs and delay in implementation. Therefore, infrastructure and initiatives should be supported to produce $\mathrm{B} / \mathrm{BT}$ control materials domestically.

To Cite : Sayın B, Bayav A, Beşen T, Karamürsel D, Çelikyurt MA, Emre M, Kuzgun M, Yılmaz ŞG, Arslan S 2020. Üreticilerin Biyolojik ve Biyoteknik Mücadele Uygulamalarına Bakışı ve Çevre Duyarlılıklarının Belirlenmesi. KSÜ Tarım ve Doğa Derg 23(2): 453-466. DOI: 10.18016/ksutarimdoga.vi.599085.

\section{GİRIŞ}

Tarım sektörü, canlıların besin ihtiyacını karşılama ve kırsal alanda yaşayan nüfusun geçim kaynağını oluşturmanın yanında, işleme sanayiine hammadde temini sağlayarak kentsel alanda da istihdam olanağ 1 yaratmaktadır. Tarımsal ürünlerin verim ve kalitesini artırmanın yolu modern tarım tekniklerinin ve girdilerinin kullanılmasından geçmektedir. Modern tarımın tamamlayıcı bir bileşeni olarak bitki koruma ürünlerinden pestisitler de bu girdilerden biridir (Tiryaki ve ark, 2010).

Türkiye'de pestisit tüketimi, gelişmiş ülkelere göre oldukça düşük olmakla birlikte bölgeler arasında farklılaşmaktadır. Entansif tarım yapılan Akdeniz, Ege gibi bölgelerin tüketimi, Türkiye ortalamasının çok üzerinde olup bu bölgelerdeki pestisit kullanımının gelişmiş ülkeler düzeyine yaklaştığı görülmektedir (Delen ve ark, 1995; Delen ve Ark, 2005). Günümüzde sürdürülebilir tarımsal üretim, insan sağlığı, çevre ve biyolojik çeşitliliğin korunması giderek daha fazla önem kazandığından özellikle pestisitler sorgulanmaya başlanmıştır (Bulut ve Göçmen, 2000). Yoğun pestisit kullanımı hastalık, zararlı ve yabancı otların ilaçlara dayanıklılık mekanizmalarının gelişmesine yol açarken, doğadaki yararlı organizmaların olumsuz etkilenmesine neden olmakta, üründe oluşacak pestisit kalıntıları ise insan sağlığı için sorun teşkil etmektedir. Bunun yanında özellikle gelişmiş ülkelerin satın alacakları üründe olabilecek ilaç kalıntısı miktarı için sınırlar belirleyerek, sağlıklı ürüne müşteri olma eğilimi, ihracatta rekabet gücünü azaltan bir faktör olarak karşımıza çıkmaktadır.

İnsan ve çevre sağllğının korunması ve sürdürülebilir tarımın yapılabilmesi için 1970 yılında başlatılan entegre mücadele çalışmalarının ana hedefi, üreticilerin eğitilerek entegre mücadele programlarını uygulayabilecekleri düzeye erişmeleridir (Karaturhan 2005). Alternatif mücadele yöntemlerinin başında ise entegre mücadelenin de en önemli bileşenlerinden olan biyolojik ve biyoteknik mücadele yöntemleri gelmektedir. Biyolojik mücadele yöntemi ile doğada bulunan yararlı organizmalar kullanılarak, bitkisel üretimde ekonomik kayıplara yol açan zararlı organizmalarla mücadele edilmektedir. Biyoteknik mücadele ise zararlı organizmaları direk öldürmek yerine bazı tekniklerle normal seyrindeki biyolojik ve fizyolojik davranışları engelleyerek kontrol altına almak anlamına gelmektedir (Birişik ve ark, 2013).

Klasik biyolojik mücadele amaçlı çalışmalar ülkemize ilk kez 1910 yılında Torbalıkoşnil'e karşı parazitoit ve predatör ithali ile başlamıştır. Daha sonra elma pamuklubiti, dut kabuklubiti, süne, turunçgil unlubiti, harnup güvesi, kırmızı kabuklubit, esmer salyangoz, yaprakbitleri, defne beyazsineği ve turunçgil beyazsineğine karşı faydalı böceklerin ithali yapılmıştır. Türkiye'de biyoteknik mücadele konusunda yapılan çalışmalar ise çok eski tarihlere dayanmamaktadır. 1980'li yıllarda farklı meyve, bağ ve sebze türlerinde zarar yapan böceklere karşı başlatılan Ar-Ge çalışmaları sonucunda, biyoteknik mücadele yönteminin etkinliği ortaya koyulmuş ve teknik talimatlarda bu mücadele yöntemine yer verilmiştir. Özellikle organik tarımın gelişmesine paralel olarak bu ürünler ithal edilerek yaygın olarak kullanılmaya başlanmıştır (Birişik ve ark, 2013).

Onuncu Kalkınma Planı kapsamında hazırlanan Bitkisel Üretim Özel İhtisas Komisyonu Raporu'nda; öncelikle bitki sağlığı çalışmalarının Avrupa Birliği'ne ve uluslararası standartlara uygun olarak yürütülmesinin sağlanarak, zararlı organizmalardan kaynaklanan kayıpların \% 35'ten \% 25'e indirilmesi ve biyolojik ve biyoteknik mücadele ürünlerinin toplam bitki koruma ürünleri içindeki \% 1 civarında olan pazar payının \% 25’e çıkarılması hedeflenmiştir (Anonim, 2014 a). Ayrıca biyolojik ve biyoteknik mücadele materyallerinin kullanımının 2010 yılından itibaren Tarım ve Orman Bakanlığı tarafından destekleme kapsamına alınması, doğal çevreyi ve 
insan sağlığını koruma ve ihracatı engelleyecek ilaç kalıntısı problemini çözmeye yönelik tedbirlerdendir. Başta destekleme uygulamaları olmak üzere alınan tedbirler Türkiye'de, biyolojik ve biyoteknik mücadele araçlarının kullanımının yıllar içinde artış göstermesini sağlamıştır (Anonim, 2015).

$\mathrm{Bu}$ araştırmada çalışma alanı olarak seçilen ve Batı Akdeniz Bölgesi kapsamına giren Antalya, Isparta ve Burdur İlleri sahip olduğu tarım potansiyeli ile Türkiye'nin önemli tarım merkezlerindendir. Türkiye İstatistik Bölge Birimleri Sinıflandırmasına göre TR 61 Batı Akdeniz Bölgesi olarak adlandırılan bölge; coğrafi konumu, verimli toprakları, uygun iklim koşulları, yeterli su kaynakları, büyük pazarlara yakınlığı ile tarımsal üretim için oldukça elverişli koşullara sahiptir. Bölgede 41 çeşit sebze ve 36 çeşit meyve yetiştirilmektedir. Türkiye'nin toplam narenciye üretiminin \% 30'u ve toplam tropikal meyve üretiminin \% 55’i Antalya'da yapılmakta olup bölgenin yaş meyve ve sebze ihracatı yıllık 300 milyon dolardır (Anonim 2014 b). Bölge Türkiye'deki elma, kiraz, gül, haşhaş, anason, seracılık, süs bitkileri, tıbbi aromatik bitkiler ve tropikal meyveler üretiminde önemli bir paya sahiptir. Dünyada Çin ve A.B.D.'nden sonra 3'üncü sırada yer alan Türkiye elma üretiminin yaklaşık \% 29.8'ini Batı Akdeniz Bölgesi karşılamaktadır. Akdeniz ülkelerinin toplam sera alanının yaklaşık \% 18’i Türkiye'de bulunmakta, Türkiye'de mevcut sera üretiminin \% 85’i Batı Akdeniz Bölgesi'nde yapılmaktadır. Bölge kalkınmasında gelişme ekseni olarak belirlenen beş başlıktan birini oluşturan Tarımda Modernizasyonun ve Kırsal Kalkınmanın Sağlanması başlığının öncelikleri arasında Bitkisel Üretimde Modernizasyonun Sağlanması ve İyi Tarım Uygulamalarının Yaygınlaştırılması gelmektedir (Anonim, 2014 b). Bu bağlamda biyolojik ve biyoteknik mücadele yöntemlerinin kullanımının yaygınlaştırılması bölge için önem arz etmektedir.

Hastalık, zararlı ve yabancı otlarla mücadelede kimyasalların doğru kullanımı ve çevre dostu üretim teknikleri hakkında üreticilerin bilgi, tutum ve davranışlarının yönlendirilmesi gereklidir. Özkan ve ark. (1991) yürüttükleri araştırma kapsamında görüştükleri üreticilerin yaklaşık $\% \quad 85$ ' inin bahçelerinde gördükleri böceklerin zararlı olmadığını bildiklerini, ayrıca \% 23' ünün de turunçgil unlu bitine karşı bazı faydalı böcek türlerini temin ederek biyolojik mücadele uygulaması yaptıklarını ortaya koymuştur. Tüzel ve arkadaşları (2010) tarafından yürütülen bir çalışma kapsamında incelenen modern seraların tamamında, geleneksel seraların ise \%80'inde sarı yapışkan tuzak kullanıldığı ve bu uygulamanın hızla yayginlaştığı ifade edilmiştir. Yanar ve arkadaşları (2018) tarafından yürütülen çalışmada da, görüşülen üreticilerin $\% 26$ sinın biyolojik mücadele, \% 56 oranında üreticinin feromon tuzak, \%74 oranında üreticinin ise sarı yapışkan tuzak gibi biyoteknik mücadele yöntemlerini kullandığ tespit edilmiştir.

$\mathrm{Bu}$ çalışmanın amacı Antalya, Burdur ve Isparta İlerinde örtüaltı sebze yetiştiriciliği, turunçgil yetiştiriciliği ve elma yetiştiriciliği yapan ve zararlılarla mücadele için biyolojik ve biyoteknik (B/BT) mücadele yöntemlerini kullanan ve kullanmayan üreticilerin bu mücedele metotlarını uygulama şekilleri, yöntemler hakkında görüş ve düşünceleri, hastalık ve zararlılara karşı kimyasal mücadele uygulamaları, B/BT mücadele hakkındaki bilgi kaynakları, B/BT mücadele materyallerini kullanmama nedenleri ve üreticilerin çevresel duyarlılıklarına ilişkin bilgiler elde etmektir. Çalışmayı literatürdeki benzerlerinden ayıran en önemli fark incelenen başlıklar altında B/BT mücadele yöntemlerini uygulayan ve uygulamayan üreticiler arasında karşılaştırma yapmaktır.

\section{MATERYAL ve YÖNTEM}

\section{Materyal}

Çalışmanın ana materyalini, 2017 yllında Antalya, Isparta ve Burdur İllerine bağlı köylerde örtü altı sebze, turunçgil ve elma yetiştiriciliği yapan 216 üreticiden anket yoluyla yüz yüze görüşülerek elde edilen veriler oluşturmaktadır.

\section{Metot}

Anket uygulanacak işletme sayısının belirlenmesinde; Antalya, Burdur ve Isparta İlleri Gıda Tarım ve Hayvancılık Müdürlükleri'nden alınan 2016 yılı biyolojik ve biyoteknik mücadele desteği ödemesinden faydalanan kişi listesinden yararlanılmıştır. Varyasyon katsayısının çok yüksek (\%153) ve popülasyonun heterojen yapıda olduğu anlaşıldığından örnek seçiminde tabakalı örnekleme yöntemi kullanılmıştır. Araştırmanın temel kurgusu, B/BT mücadele yöntemlerini uygulayan ve uygulamayan üreticilerden oluşan iki grubu çeşitli konularda karşılaştırmaktır. Örnek hacmi Neyman Yöntemi ile hesaplanmıştır (Yamane 1967; Çiçek ve Erkan, 1996). Araştırmada \% 5 hata payı ve \%90 güven aralığı esas alınarak popülasyondan çekilen örnek sayısı 108 olarak belirlenmiştir. Bunun yanında; yine aynı yörede ve aynı sayıda, benzer ürün deseni ve tarımsal işletme karakteristiklerine sahip, ancak biyolojik ve biyoteknik mücadele materyallerini kullanmayan 108 üretici gayeli olarak seçilmiş bu üreticilerle de anket çalışması yapılmıştır. Anket uygulaması Antalya İlinde turunçgil, elma ve örtüaltında sebze üreten işletmelerde, Burdur ilinde son yıllarda yayla seracılığının yaygınlaştığı ilçe ve köylerdeki örtü altı domates üreticisi işletmelerde ve Isparta ilinde elma yetiştiricisi işletmelerde yapılmıştır. 
Biyolojik veya biyoteknik mücadele yöntemlerini uygulayan ve uygulamayan işletmecilerle yüz yüze görüşmede kullanmak üzere iki ayrı soru formu hazırlanmıştır.

Araştırma şu sorular üzerinde kurgulanmıştır.

1. Üreticilerin demografik özellikleri ve işletmeleri tanımlayıcı özellikler nelerdir?

2. Sahada B/BT mücadele uygulamaları ve üreticilerin konu hakkındaki düşünceleri nelerdir?

3. Üreticilerin B/BT mücadele hakkında başvuru kaynakları kimlerdir?

4. Ele alınan ürünlerin üretiminde kimyasal mücadele nasıl yapılmaktadır?

5. B/BT mücadele

kullanılmama nedenleri nelerdir?

6. Üreticilerin çevreye olan duyarlılıkları hangi düzeydedir?

Tüm değişkenler için temel tanımlayıcı istatistikler (ortalama, minimum, maksimum, standart sapma vb.) belirlenmiştir. İki bağımsız grup arasındaki farklılıklar; normal dağılım gösteren sürekli değişkenler için t testi; normal dağılım göstermeyen sürekli değişkenler için ise Mann Whitney U testi kullanılarak analiz edilmiştir.

Araştırma kapsamında görüşülen çiftçilerin çevreye olan duyarlılık düzeylerini belirlemek amaciyla Yeni Çevresel Paradigma Ölçeği kullanılmıştır (Dunlap ve ark, 2000; Cordano ve ark, 2003; Günden ve Miran, 2008). Üreticilere ölçekte yer alan ifadelere katılıp katılmadıkları sorulmuş, verilen cevaplara bağlı olarak çevresel tutumları saptanmıştır. Değerlendirmede likert ölçeğinden yararlanılmıştır. B/BT mücadele yapan ve yapmayan üreticilerin yeni çevresel paradigma ölçeği puanları arasında istatistiksel olarak anlamlı bir farklılık olup olmadığını anlamak için bağımsız örneklemler t testi yapılmıştır.

\section{BULGULAR ve TARTIŞMA}

İşletme sahibi ile ilgili tanımlayıcı bilgiler

İki grupta yer alan üreticiler; yaş, eğitim durumu, çiftçilik deneyim süresi, örgütlenme durumu ve tarım dışı gelir varlığı yönünden karşılaştırılmıştır.

Çizelge 1. İşletme sahibi ile ilgili tanımlayıcı bilgiler

Table 1. Identifying information about producers

\begin{tabular}{lllll}
\hline & Yaş (Age) & $\begin{array}{l}\text { Eğitim süresi } \\
\text { Education }\end{array}$ & $\begin{array}{l}\text { Tarımsal deneyim } \\
\text { Agricultural experience }\end{array}$ & $\begin{array}{l}\text { Tarım dişı gelir } \\
\text { Non-agricultural income }\end{array}$ \\
\hline $\begin{array}{l}\text { B/BT mücadele uygulayan } \\
\text { Applying B/BT control }\end{array}$ & 52.3 & 8.1 & 28.3 & 23289 \\
\hline $\begin{array}{l}\text { B/BT mücadele uygulamayan } \\
\text { Not applying B/BT control }\end{array}$ & 51.3 & 8.4 & 25.5 & 20281 \\
\hline
\end{tabular}

B/BT mücadele uygulayan üreticilerin \% 83.3’ü, uygulamayan üreticilerin ise \% 86.1'i olmak üzere, tüm üreticilerin \% 84.7'si tarım danışmanlığı hizmeti
Üreticiler arasında B/BT mücadele uygulayanların \% 52.8 'i, uygulamayanların \% 50.9'u 52 yaşın altında olup, B/BT mücadele uygulayan üreticilerin yaş ortalaması 52.3, B/BT mücadele uygulamayan üreticilerin yaş ortalaması ise 51.3 olarak belirlenmiştir. İki gruptaki üreticilerin yaşları arasında önemli bir farklılık yoktur.

Üreticilerin eğitim durumları incelendiğinde; B/BT mücadele uygulayan üreticilerin $\% 47.2$ si ilkokul, \% 39.8 i orta-lise mezunudur. B/BT mücadele uygulamayan üreticilerde ilkokul mezunu olanlar ile orta-lise mezunu olanların oranı eşit olup \% 42.6 olarak belirlenmiştir. Ön lisans ve üzeri eğitim alanlarin oranı, B/BT mücadele uygulayan üreticilerde \% 13.0, uygulamayan üreticilerde ise \% 14.8 dir. B/BT mücadele uygulayan üreticiler ortalama 8.1 yıl, uygulamayan üreticiler ortalama 8.4 yıl eğitim almışlardır. İki grubun eğitim süreleri arasında anlamlı düzeyde bir farklılık tespit edilmemiştir.

B/BT mücadele uygulayan üreticilerin $\% 64.8$ 'i, uygulamayan üreticilerin ise \%56.4'ü 21 yll ve daha uzun süreden bu yana çiftçilik deneyimine sahiptir. Ortalama deneyim süresi, B/BT mücadele uygulayan üreticiler için 28.3 yıl, uygulamayan üreticiler için 25.5 yıl olarak belirlenmiş olup iki üretici grubunun ortalama deneyim süreleri arasında önemli bir farklılık bulunmamıştır.

B/BT mücadele uygulayan üreticilerin \% 54.6'sinın, uygulamayan üreticilerin ise \% 49.1'inin tarım dışı geliri vardır. Tarım dışı gelir, B/BT mücadele uygulayan üreticilerde ortalama $23289 \mathrm{TL}$, uygulamayan üreticilerde ise 20281 TL'dır. İki grup arasında tarım dışı gelir yönünden anlamlı düzeyde bir farklılık tespit edilmemiştir (Çizelge 1).

Üreticilerin kooperatif, birlik vb. örgütlere üyelikleri ile ilgili olarak yapılan değerlendirmede; B/BT mücadele uygulayan üreticilerin \% 63.0'ü, uygulamayan üreticilerin ise \% 60.2'si olmak üzere tüm üreticilerin \% 61.6'sının tarım kredi kooperatifi, yöredeki üretici kooperatifi, sulama birliği veya kooperatifi, köy kalkınma kooperatifi vb. kurumlardan birine veya bir kaçına üyeliği bulunmaktadır. almadığını ifade etmiştir. Tarımsal danışmanlık hizmeti aldığını ifade eden tüm üreticilerin \% 12.1'i 3 yıl ve daha az, \% 87.9'u da 4 yıl ve daha fazla süredir 
bu hizmetten yararlandığını bildirmiştir. Bu çalışma da diğer çalışmalarda olduğu gibi Türkiye'de tarım danışmanından hizmet alan üretici sayısı ve tarımsal danışmanlık hizmetleri konusunda yetersizlikler olduğunu ortaya koymaktadır. Örneğin 2005 yılında Antalya ilinde örtü altı üretim alanlarında yapılan bir çalışmada yörede danışmanlık hizmeti verilen üretici sayısının toplam örtü altı yetiştirici sayısının sadece \% 4'ünü, üretim alanının da toplam örtü altı üretim alanının \% 7.6'sını oluşturduğu tespit edilmiştir (Ateş ve Sayın, 2008)

\section{İşletme ile ilgili tanımlayıcı bilgiler}

B/BT mücadele uygulayan ve uygulamayan tarım işletmeleri, arazi varlığ̣ (toplam işlenen ve nadasboş), mülkiyet durumu (mülk, kiralanan, ortak işletilen ve kiraya verilen), sulanma durumu (sulanan ve sulanmayan), parsel sayısı, işletme faaliyet türü, işletme varlıklarının toplam ekonomik büyüklüğü bakımından karşılaştırılmıştır. Ortalama işlenen arazi büyüklüğü, $\mathrm{B} / \mathrm{BT}$ mücadele uygulayan işletmelerde $51.4 \mathrm{da}$, uygulamayan işletmelerde ise 41.9 dekardır. Mülk arazi büyüklüğü B/BT mücadele uygulayan işletmelerde $38.5 \mathrm{da}$, uygulamayan işletmelerde ise 38.4 dekardır. B/BT mücadele uygulayan işletmelerde kiralanan arazi büyüklüğü ortalama $9.1 \mathrm{da}$, uygulamayan işletmelerde ise 3.7 dekardır. B/BT mücadele uygulayan işletmelerde ortakçılıkla işletilen arazi büyüklüğü ortalama $2.8 \mathrm{da}$, uygulamayan işletmelerde ise 0.4 dekardır. İki grup arasında, ortalama işlenen ve kiralanan arazi büyüklüğü bakımından anlamlı bir fark bulunmamıştır. B/BT mücadele uygulayan ve uygulamayan iki grubun ortakçılıkla işletmekte oldukları arazi büyüklüklerinin ortalamaları arasında istatistiksel olarak anlamlı bir farklılık vardir.

Antalya ili Kaş ilçesinde biyolojik mücadele yapan ve yapmayan işletmelerin karşlaştırıldığı benzer bir araştırmada, biyolojik mücadele yapmayan işletmelerin, biyolojik mücadele yapan işletmelere oranla daha fazla ortakçılıkla işletildiği, ortakçılığın azaltılmasına yönelik önlemler alınmasının bu işletmelerin etkinliğine olumlu etki edeceği bildirilmiştir (Yıldırım ve ark, 2016). Kiraya verilen ve sulanan arazi büyüklüğü bakımından her iki grup arasinda anlamlı bir fark yoktur. Sulanmayan arazi büyüklüğü $\mathrm{B} / \mathrm{BT}$ mücadele uygulayan işletmelerde ortalama $5 \mathrm{da}$, uygulamayan işletmelerde ise 0.45 dekardır. B/BT mücadele uygulayan ve uygulamayan iki grubun sulanmayan arazi büyüklüklerinin ortalamaları arasında da istatistiksel olarak anlamlı bir farklılık tespit edilmiştir. Parsel sayısı B/BT mücadele uygulayan işletmelerde 1-50 arasında değişmekte olup ortalama 5.8 adet olarak belirlenmiştir. B/BT mücadele uygulamayan işletmelerde ise parsel sayısı 1-20 arasında değişirken ortalama olarak 4.5 adettir. İki grup arasında parsel sayısı bakımından anlamlı bir fark bulunmamıştır (Çizelge 2).

Çizelge 2. İşletme arazi varlığı, mülkiyet ve sulanma durumu, parsel sayısı

Table 2. Farm land assets, ownership and irrigation status, number of parcels

\begin{tabular}{|c|c|c|c|c|c|c|c|c|c|}
\hline & \multicolumn{4}{|c|}{$\begin{array}{l}\text { B/BT mücadele uygulayan } \\
\text { Applying } B / B T \text { control }\end{array}$} & \multicolumn{4}{|c|}{$\begin{array}{l}\text { B/BT mücadele uygulamayan } \\
\text { Not applying B/BT control }\end{array}$} & \multirow[t]{2}{*}{$\begin{array}{l}\text { Mann } \\
\text { Whitney U }\end{array}$} \\
\hline & $\begin{array}{l}\text { Min. } \\
\text { Min. }\end{array}$ & $\begin{array}{l}\text { Max. } \\
\text { Max. }\end{array}$ & $\begin{array}{l}\text { Ort. } \\
\text { Mean }\end{array}$ & $\begin{array}{l}\text { Std. Sp } \\
S D\end{array}$ & $\begin{array}{l}\text { Min. } \\
\text { Min. }\end{array}$ & $\begin{array}{l}\text { Max. } \\
\text { Max. }\end{array}$ & $\begin{array}{l}\text { Ort. } \\
\text { Mean }\end{array}$ & $\begin{array}{l}\text { St. Sp } \\
S D\end{array}$ & \\
\hline $\begin{array}{l}\text { Toplam işlenen (da) } \\
\text { Total planted area (da) }\end{array}$ & 1 & 750 & 51.4 & 84.8 & 3 & 400 & 41.9 & 60.2 & .158 \\
\hline $\begin{array}{l}\text { Nadas-Boş (da) } \\
\text { Fallow (da) }\end{array}$ & 0 & 105 & 1.5 & 10.5 & 0 & 15 & 0.3 & 1.8 & .740 \\
\hline $\begin{array}{l}\text { Mülk (da) } \\
\text { Owner(da) }\end{array}$ & 0 & 400 & 38.5 & 50.7 & 0 & 400 & 38.4 & 60.5 & .406 \\
\hline $\begin{array}{l}\text { Kiralanan (da) } \\
\text { Leased (da) }\end{array}$ & 0 & 550 & 9.1 & 53.9 & 0 & 70 & 3.7 & 11.3 & .983 \\
\hline $\begin{array}{l}\text { Ortak işlenen (da) } \\
\text { Partner (da) }\end{array}$ & 0 & 72 & 2.8 & 10.9 & 0 & 15 & 0.4 & 2.2 & .043 \\
\hline $\begin{array}{l}\text { Kiraya verilen (da) } \\
\text { Given for rent (da) }\end{array}$ & 0 & 4 & 0.1 & 0.4 & 0 & 36 & 0.3 & 3.5 & .995 \\
\hline $\begin{array}{l}\text { Sulanan (da) } \\
\text { Irrigation }\end{array}$ & 0 & 750 & 46.5 & 83.5 & 3 & 400 & 41.9 & 60.2 & .544 \\
\hline $\begin{array}{l}\text { Sulanmayan (da) } \\
\text { Not irrigation (da) }\end{array}$ & 0 & 105 & 5.0 & 16.7 & 0 & 15 & 0.5 & 2.3 & .005 \\
\hline $\begin{array}{l}\text { Parsel sayısı (adet) } \\
\text { Number of parcel } \\
\text { (number) }\end{array}$ & 1 & 50 & 5.8 & 6.2 & 1 & 20 & 4.5 & 3.8 & .079 \\
\hline
\end{tabular}


B/BT mücadele uygulayan işletmelerde, B/BT mücadele materyalleri kullanılarak mücadele uygulanan arazi büyüklüğu ortalama $30.6 \mathrm{da}$, bu alanın toplam arazi içerisindeki payı ise ortalama \% 62.7 olarak belirlenmiştir. İşletmelerde hangi faaliyet türünün ön plana çıktığ mücadele uygulayan işletmelerin \% 88'inde bitkisel üretim faaliyeti gerçekleştirildiği, \% 12'sinde bitkisel üretimin yanında hayvansal üretimin de yapıldı $\breve{g}_{1}$ anlaşılmaktadır. B/BT mücadele uygulamayan işletmelerde ise bu oranlar sırasiyla \% 91.7 ve \% 8.3 olarak belirlenmiştir. B/BT mücadele uygulayan işletmelerde işletme varlıklarının toplam ekonomik büyüklüğü 100000 TL ye kadar olanlar \% 7.4, 100001 - 500000 TL arasinda olanlar \% 24.1, 500001 1000000 TL arasinda olanlar \% 20.4, 1000000 3000000 arasinda olanlar \% 28.7, 3000000 TL ve daha fazla olanlar ise \% 19.4 oranındadır. B/BT mücadele uygulamayan işletmeler için ise bu değerler sirasiyla \% 7.5, \% 23.1, \% 20.4, \% 34.2 ve $\% 14.8$ olarak belirlenmiştir.

Biyolojik/biyoteknik mücadele uygulamaları ve üreticilerin konu hakkında düşünceleri

Zararlılara karşı uzun yıllardan beri kullanılan kimyasal mücadele uygulamalarına alternatif olacak mücadele yöntemlerinin tercih edilmesi, tarımsal ürünlerde kalite ve verimin artmasını, insan ve çevre sağlığının güvence altına alınmasını sağlayacaktır (Topuz, 2005). Bitkisel üretimde zararlılarla mücadele amacıyla B/BT mücadele uygulandığında, hedef alınan zararlıya yönelik kimyasal mücadele sayısı ve kullanılan insektisit miktarında önemli ölçüde azalma sağlanmaktadır. Araştırma sonuçlarına göre; örtü altında biber yetiştiren üreticilerin \% 23.1'i biyoteknik ve biyolojik mücadele uygulamalarını bir arada uygularken, \% 3.8'i sadece biyoteknik, \% 73.1'i ise sadece biyolojik mücadele yöntemini kullanmaktadır. Örtü altında domates yetiştiren üreticilerin \% 7.7'si biyoteknik ve biyolojik mücadele uygulamalarını bir arada uygularken, \% 92.3'ü ise sadece biyolojik mücadele yöntemini kullanmaktadır. Turunçgil yetiştiricisi üreticilerin \% 29'u biyoteknik ve biyolojik mücadele uygulamalarını bir arada uygularken, \% 35.5'i sadece biyoteknik, \% 35.5 ' $\mathrm{i}$ ise sadece biyolojik mücadele yöntemini kullanmaktadır. Elma üreticilerinin tamamı iç kurdu zararlısı ile mücadele amacıyla sadece biyoteknik mücadele uygulamaktadır.

Faydalı böceklerin pazarlamasını yapan firma yetkilileri biyolojik ve biyoteknik mücadele aparat ve etmenlerinin satışı ile birlikte üreticilere uygulama sürecine ilişkin teknik tavsiyeler de yapmaktadır. Buna göre örtü altı sebze yetiştiriciliğinde; beyaz sinek mücadelesi için dikimden sonra üçüncü haftada bir kez, dördüncü veya beşinci haftada bir kez olmak üzere iki kez, yaprak biti, kırmızı örümcek ve diğer minör zararlılar için de bir kez uygulama yapılması tavsiye edilmektedir. Söküm aşamasına kadar da zararlı görülme durumuna göre uygulamaların tekrarlanması istenmektedir. Örtü altı sebze üreticilerinin teknik danışmanlar tarafından biyolojik mücadele uygulamasını en az üç kez yapmaları yönünde bilgilendirildiği anlaşılmaktadır. Ancak anket formu kapsamında yapılan görüşmeler, üreticilerin önemli bir bölümünün bu teknik tavsiyelere çok fazla uymadığını ortaya koymaktadır. Şöyle ki biber yetiştiriciliğinde biyolojik mücadele uygulayan üreticilerin \% 76's $1 \mathrm{kez}, \%$ 8'i $3 \mathrm{kez}, \%$ 12 'si $4 \mathrm{kez}$ ve \% 4'ü $5 \mathrm{kez}$ uygulama yaptığını ifade etmiştir. Domates yetiştiriciliğinde biyolojik mücadele uygulayan üreticilerin \% 23.1'i $1 \mathrm{kez}, \% 69.2$ 'si $2 \mathrm{kez}$, $\%$ 7.7'si 4 kez uygulama yaptığını ifade etmiştir.

Turunçgil yetiştiriciliğinde ise biyolojik mücadele uygulayan üreticilerin tamamı tek seferlik uygulama yaptığını ifade etmiştir. Biyolojik mücadelenin bu alanlarda çevre bahçeleri de içine alan bütüncül bir yaklaşımla yürütülememesi en önemli handikaptır.

Üreticiler B/BT mücadele uygulaması sayesinde ürünün hasat edilme takviminde kısıtlanmadıklarını, kimyasal kullanımında gerekli olan yarılanma süresini beklemek zorunda kalmadıklarını ifade etmişlerdir. Üreticilerin B/BT mücadele uygulamalarını benimsemelerinde, uygulamaların sağladığı avantajların da etkisi bulunmaktadır. Çoğunlukla küçük aile işletmeleri ölçeğinde yürütülen örtü altı sebze yetiştiriciliği faaliyetinde, yoğun işgücü kullanımı gerektiğinden uygulama kolaylı̆̆ sağlayan B/BT yöntemlerine ilgi artmaktadir.

Hastalık, zararlı ve yabancı otlarla mücadelede kimyasalların doğru kullanımı ve çevre dostu üretim tekniklerine ilişkin üretici bilincinde yaşanan olumlu değişim literatüre de yansımıştır. Çelik ve Karakaya (2017)'nın Bingöl İli Adaklı İlçesi'nde elma üreticilerinin tarımsal ilaç kullanımı ile ilgili bilgi tutum ve davranışlarını değerlendirdikleri çalışmalarında; üreticilerin \%70'inin tarımsal ilaçların çevreye ve diğer canlılara zararlı etkileri konusundaki ifadelere kesinlikle katıldıklarını ifade ederken, tarımsal ilaçların çevreye ve diğer canlılara olan zararlı etkileri konusundaki ifadelere kesinlikle katılmiyorum diyen üretici olmadığı sonucu belirlenmiştir. Bunun yanı sıra Karabat ve Atış (2012) tarafından bildirilen, Manisa İli bağ alanlarında incelenen işletmelerde, üreticilerin \% 70.1'inin geleneksel ilaçlama yöntemi yerine, çevre dostu ilaçlardan oluşan bir ilaçlama modelini uygulamak için fazladan ödeme yapabileceği bilgisi kayda değerdir. Ancak yüksek kazanç getiren ürünlerin üretiminde bu durumun söz konusu olabileceği göz ardı edilmemelidir. 
Araştırma kapsamında görüşülen üreticiler, zararlılara karşı kimyasal kullandıklarında ilaç uygulama sıklığı ve sayısı nedeniyle hem kendi sağlıklarının ve ürün sağlığının tehdit edildiğini hem de daha fazla zaman harcandığını, B/BT mücadele materyalleri kullanıldığında ise ürünlerin sağlıklı olmasının yanında kendi sağlıklarının da bozulmadığını ve zamandan da tasarruf edildiğini ifade etmişlerdir.

Buna karşılık uygulamada yaşanan aksaklılar da söz konusudur. Üreticilerin serada hastalık ve zararlı takibini yeterli ölçüde yapmadıkları, etkilenen bitkileri seradan uzaklaştırmakta geç kaldıkları, serada zararlının görülmesi ile uygulanacak doğal düşmanların siparişinden teminine kadar geçen süre içinde zararlı popülasyonunun arttığg, bu nedenle de yayılımı önlemek için kimyasal kullanmak zorunda kaldıkları görülmüştür. Üreticilerin, süreci bizzat kendilerinin takip etmesi gerektiğinin bilincinde olmadıkları gözlenmiştir. Aparat ve canlı materyalleri pazarlayan firmaların rutin ziyaretleri zararlılarla mücadele sürecinin sağlıklı gelişimi için yeterli olmamaktadir.

Araştırma kapsamında görüşülen üreticilerden zararlılarla mücadelede $\mathrm{B} / \mathrm{BT}$ mücadele metodunu kullanma nedenlerini önem sirasına göre bildirmeleri istendiğinde ilk iki tercihleri sirasiyla, "İnsan sağllğını düşündüğüm için" ve "Doğal çevreyi kirletmemek için” olmuştur (Çizelge 3).

Çizelge 3. Üreticilerin B/BT mücadele kullanma nedeni tercihleri

Table3. Causes of producers using B/BT control

\begin{tabular}{|c|c|c|c|c|c|c|}
\hline & \multicolumn{2}{|c|}{ 1.tercih (First choice) } & \multicolumn{2}{|c|}{ 2.tercih(Second choice) } & \multicolumn{2}{|c|}{ 3.tercih(Third choice) } \\
\hline & Adet(Number) & $\%$ & Adet(Number) & $\%$ & $\operatorname{Adet}($ Number $)$ & $\%$ \\
\hline $\begin{array}{l}\text { Doğal çevreyi kirletmemek için } \\
\text { To avoid polluting the natural environment }\end{array}$ & 7 & 6.5 & 37 & 34.3 & 24 & 22.2 \\
\hline $\begin{array}{l}\text { İnsan sağllğını düşündüğüm için } \\
\text { For thinking about human health }\end{array}$ & 40 & 37.0 & 29 & 26.9 & 26 & 24.1 \\
\hline $\begin{array}{l}\text { Mücadele masraflarını düşürmek için } \\
\text { To reduce fighting costs }\end{array}$ & 9 & 8.3 & 14 & 13.0 & 16 & 14.8 \\
\hline $\begin{array}{l}\text { Pazarlama kolaylığı için } \\
\text { For marketability }\end{array}$ & 6 & 5.6 & 21 & 19.4 & 16 & 14.8 \\
\hline $\begin{array}{l}\text { Ürünümü daha iyi fiyata satmak için } \\
\text { To sell the product at a good price }\end{array}$ & 1 & 0.9 & 2 & 1.9 & 7 & 6.5 \\
\hline $\begin{array}{l}\text { Firma/komisyoncu ile anlaşma gereği } \\
\text { By agreement with the company/commisioner }\end{array}$ & 0 & 0.0 & 0 & 0.0 & 2 & 1.9 \\
\hline
\end{tabular}

B/BT mücadale yöntemlerini uygulamanin halihazırda maliyetleri azaltma, farkl fiyattan ürün satma veya pazarlama kolaylığı sağlama bakımından bir avantaj oluşturmadığı üreticilerin beyanları ile de tespit edilmiştir.

B/BT mücadele uygulamalarını kullanan üreticilere bazı ifadelere katılıp katılmadıkları sorulmuştur. Buna göre "B/BT mücadele materyallerinin maliyeti yüksek” ifadesine üreticilerin \% 41.7'si kesinlikle katılmaktadır. Bu ifade için ölçek ortalaması (3.74) olarak hesaplanmış olup, üreticilerin bu ifade üzerinde olumlu yönde hemfikir oldukları anlaşılmaktadır. Üreticiler, büyük oranda, B/BT mücadele uygulaması ile ilgili, yeterli bilgiye sahip olduklarını, sermaye açısından sorunları olmadığını ifade etmişlerdir. "B/BT mücadele uygulaması için sermaye yetersizliği" ifadesine üreticilerin \% 49.1’i kesinlikle katılmamaktadır. "B/BT mücadelenin başarısı kimyasal mücadeleden düşük" şeklindeki yargı bildiren ifadeye üreticilerin \% 23.1'i kesinlikle katıldığını, \% 38'i ise kesinlikle katılmadığını ifade etmiştir. "B/BT mücadele ile üretilen ürünler daha iyi kazanç sağlar" ifadesine ise üreticilerin \% 36.1'i kesinlikle katılmadığını, \% 11.1’i katılmadığını ifade etmiş, \% 17.6'sı ise kararsız kalmıştır (Çizelge 4). Bu ifade için ölçek ortalaması (2.72) olarak hesaplanmış olup, üreticilerin bu ifadeye katılıp katılmamakta kararsız kaldığı anlaşılmaktadır. Üreticilerin beklentisi B/BT mücadele ile üretilen ürünlerin pazarda farklı bir fiyat bulması yönündedir. Üreticiler, toptancı haline götürdükleri ürünlerinin B/BT mücadele uygulaması ile üretilmesinin komisyoncu ve tüccarlar tarafından dikkate alınmadığını ifade etmişlerdir. Ülkemizde tüketicilerin de çevre dostu ve insan sağlığını gözeten uygulamalarla üretilen ürünlere farklı fiyat ödeme istekliliğinin yeterli ölçüde gelişmemiş olduğu literatürde bildirilmiştir. Örneğin Karabaş ve Gürler (2011) organik ve konvansiyonel tarım yapan üreticileri karşılaştırdıkları bir çalışmada, incelenen işletmelerde üreticilerin teknik sorunlardan çok, tüketiciye ulaşma, pazar özellikleri ve talep yetersizliği gibi ekonomik faktörlerin daha ağırlıkta olduğu sorunları dile getirdiklerini bildirmişlerdir. Sayın ve ark. (2015) tarafından yapılan çalışmada da, iyi tarım uygulamaları yapan üreticilerin $\%$ 30.4'ünün ürünün pazarda diğer ürünlerden farklı fiyata satılması gerektiği görüşünde oldukları ifade edilmiştir. Entegre mücadele yöntemleri kullanılarak yetiştirilen ürünlere farklı fiyat verilememesi bu yöntemlerin yaygınlaşmasının önündeki engeller arasındadır (Karaturhan ve ark. 2005). 
Çizelge 4. B/BT mücadele yapan üreticilerin bazı ifadelere katılım durumu (\%)

Participation of producers using B/BTcontrol to some statements

\begin{tabular}{|c|c|c|c|c|c|c|}
\hline & 1 & 2 & 3 & 4 & 5 & Ort \\
\hline $\begin{array}{l}\mathrm{B} / \mathrm{BT} \text { mücadele materyallerinin maliyeti yüksek } \\
\text { High cost of B/BT conrol materials }\end{array}$ & 11.1 & 10.2 & 13.9 & 23.1 & 41.7 & 3.74 \\
\hline $\begin{array}{l}\text { B/BT mücadele hakkında bilgi yetersizliği } \\
\text { Lack of information on B/BT control }\end{array}$ & 42.6 & 30.6 & 16.7 & 3.7 & 6.5 & 2.01 \\
\hline $\begin{array}{l}\text { B/BT mücadele uygulaması için sermaye yetersizliği } \\
\text { Lack of capital for applying B/BT control }\end{array}$ & 49.1 & 20.4 & 13.9 & 7.4 & 9.3 & 2.07 \\
\hline $\begin{array}{l}\text { B/BT mücadelenin başarısı kimyasal mücadeleden düşük } \\
\text { Success of } B / C T \text { control is lower than chemical control }\end{array}$ & 38.0 & 14.8 & 15.7 & 8.3 & 23.1 & 2.64 \\
\hline $\begin{array}{l}\text { B/BT mücadele ile üretilen ürünler daha iyi kazanç sağlar } \\
\text { Products produced with } B / B T \text { control provide better profit }\end{array}$ & 36.1 & 11.1 & 17.6 & 14.8 & 20.4 & 2.72 \\
\hline
\end{tabular}

(1)Kesinlikle katılmıyorum (2) Katılmıyorum (3) Orta derecede (4)Katılıyorum (5) Kesinlikle Katılıyorum

(1) Strongly disagree (2) Disagree (3) Neutral (4) Agree (5) Strongly agree

\section{Biyolojik/biyoteknik mücadele hakkında bilgi kaynağı}

Biyolojik mücadele uygulamasının belirli bir bilgi birikimi gerektirmesi nedeniyle üreticiler tarafindan kullanılmasında zaman zaman sorunlar yaşanmakta, bu doğal düşmanların etkin bir şekilde kullanımı için yaygın bir danışmanlık hizmetinin sunulması büyük önem taşımaktadır (Kılınçer ve ark, 2010). Ege Bölgesi'nde entegre mücadelenin yayımında karşılaşılan sorunların incelendiği bir çalışmada, entegre mücadelenin yayılmasına yönelik engellerin tarım teşkilatı personelinden kaynaklananlar, üreticilerden kaynaklananlar ve diğer sorunlar olarak üç başlık altında toplandığı bildirilmiştir (Karaturhan, B ve ark., 2005). Elma yetiştiriciliğinde entegre mücadele yönteminin geliştirilebilmesi/yaygınlaştırılabilmesi için yapılması gerekenler konusunda zirai ilaç bayilerinin görüşlerini inceleyen Gül ve arkadaşları (2014), üreticilerin eğitilmesi, bilinçlendirilmesi (\%50), yayım çalışmalarına gereken önemin verilmesi $(\% 17.2)$ ve toplantılara üretici katılımının sağlanması (\%10.3) gibi öneriler elde etmiştir.

Araştırma kapsamında görüşülen üreticilerden B/BT mücadele uygulaması yapanlara $\mathrm{B} / \mathrm{BT}$ mücadele yöntemi ile ilgili bilgiye ihtiyaç duyduklarında hangi kurumlara başvurdukları sorulmuş, \% 50 oranında üretici Tarım ve Orman Bakanlığı'nın yereldeki teşkilatına, \% 44 oranında üretici $\mathrm{B} / \mathrm{BT}$ mücadele ürünlerini satın aldıkları firmalara, \% 38 oranında üretici ilaç ve gübre temin ettikleri bayilere, \% 10.2 oranında üretici ise tarım danışmanlarına başvurduğunu beyan etmiştir. Saha gözlemleri ve üreticilerin beyanları, üreticilerin $\mathrm{B} / \mathrm{BT}$ mücadele uygulamalarindan haberdar olmaları konusunda Tarım ve Orman Bakanlığı'nın ilçe teşkilatı teknik personelinin önemli rol oynadığını göstermiştir. Uygulamaların destekleme kapsaminda olmasinın yayım personelinin elini güçlendirdiği ve yayım faaliyetlerinin çiftçi üzerindeki etkisini artırdığı düşünülmektedir.

\section{Hastalık ve zararlılara karşı kimyasal mücadele}

Hastalık ve zararlılara karşı bitki sağlığını korumak amacıyla kimyasal içerikli ilaçlar yaygın olarak kullanılmaktadır. Aydın'da yapılan bir çalışmada üreticilerin $\% \quad 86.0^{\prime}$ sının ortaya çıkan bitki zararlılarını yok etmek amacıyla kimyasal savaş yöntemini tercih ettiği bildirilmiştir (Boz ve ark,1998). Orta Sakarya havzasında yapılan bir çalışmada, üreticilerin \% 78.8'inin tarla ve bahçelerinde hastalık ve zararlılar gözlenmeden ilaç kullandığ 1 ifade edilmektedir (Tanrıvermiş, 2000). Benzer biçimde İçel'de yürütülen bir çalışmada da üreticilerin \% 58.9'unun zararlı görülmediği zaman bile ilaçlama yaptığı saptanmıştır (Zeren ve ark, 1999). Ancak üretim alanlarında bilinçsiz ve yoğun pestisit kullanımının, zararlıların ilaçlara duyarlılığının azalmasına ve dayanıklılık mekanizmalarının gelişmesine neden olduğu ve mücadele maliyetlerini giderek arttırdığg da bilinen bir gerçektir. Özellikle zararlılara yönelik kimyasal mücadele uygulama sayısında azalma sağlaması, daha az işgücü istemesi, insan sağllğını gözeten ve çevre dostu bir yöntem olması B/BT mücadele yöntemlerini zararlılarla mücadelede önemli bir alternatif kılmakta, hastalıklarla mücadelede ise B/BT beraberinde kimyasal mücadeleye devam edilmektedir.

Örtü altı sebze yetiştiriciliği yapan üreticiler arasında B/BT mücadele uygulayan grupta yer alanlar, hastalık ve zararlılarla mücadele amaçlı olarak bir üretim sezonunda ortalama $12.3 \mathrm{kez}$, uygulamayan grupta yer alanlar ise $23.4 \mathrm{kez}$ kimyasal ilaç kullandığını ifade etmiştir. Yapılan istatistiksel analizde B/BT mücadele uygulayan ve uygulamayan örtü altı sebze üreticilerinden oluşan iki grubun kimyasal ilaçlama sayısı ortalamaları arasında anlamlı düzeyde bir farklılık $(\mathrm{p}<0.01)$ bulunmuştur (Çizelge 5). Bunun yanında bu ilaçların kullanımının doğru ve tekniğine uygun olarak yapılması için teknik bilgi desteğine ihtiyaç duyulmaktadır. B/BT mücadele uygulayan üreticilerin $\% 87.8$ ' $\mathrm{i}$ uygulamayanlarm ise \% 85.4'ü kimyasal ilaçlarla mücadele hakkında bilgi aldıklarını ifade etmişlerdir. 
Çizelge 5. Kimyasal mücadele uygulamasına ilişkin bilgiler

Table 5. Information on chemical control

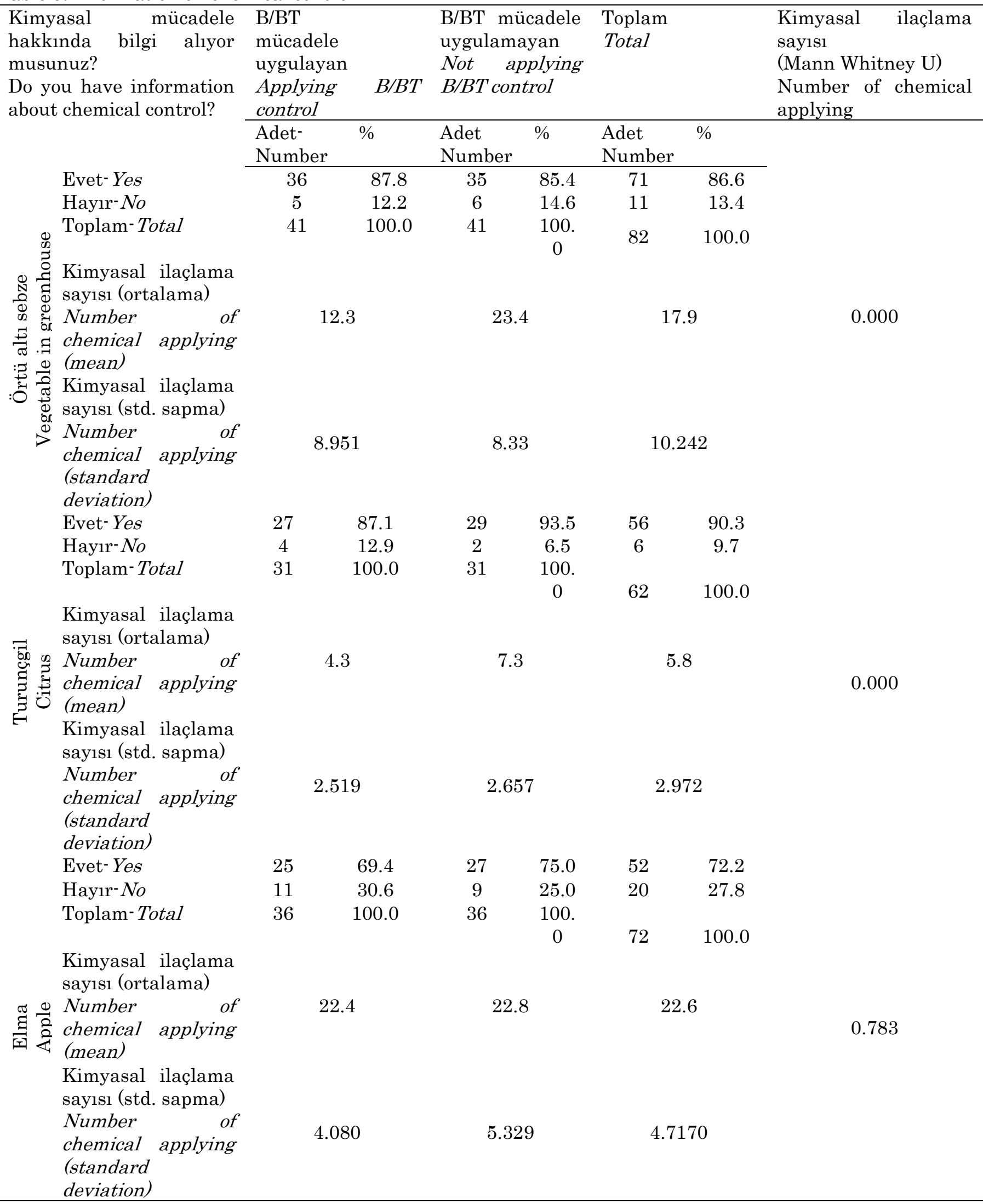

Turunçgil üretim alanlarında görülen zararlılara karşı genellikle kimyasal mücadele uygulandığı, oysa turunçgil ekosisteminde çok fazla parazitoit ve predatör türlerin doğal olarak bulunduğu ve 
uygulanan kimyasalların başta bu doğal düşmanlar üzerinde olmak üzere bir çok olumsuz etki yarattığ bildirilmiştir (Satar ve ark, 2012). Turunçgil üretim faaliyetinde B/BT mücadele yöntemi kullanımı, doğal ortamda bulunan veya insan eliyle bahçeye salınan avc1 türlere zarar vermemek adına, kimyasal mücadele kullanımının önemli ölçüde azalmasını sağlamaktadır. Görüşülen turunçgil üreticileri arasında B/BT mücadele uygulayan grupta yer alanlar üretim sürecinde hastalık ve zararlılarla mücadele amaçlı olarak ortalama 4.3 kez, uygulamayan grupta yer alanlar ise $7.3 \mathrm{kez}$ kimyasal ilaç kullandığını ifade etmişlerdir. İki grubun kimyasal ilaçlama sayısı ortalamaları arasında anlamlı düzeyde bir farklılık $(\mathrm{p}<0.01)$ vardır. B/BT mücadele uygulayan turunçgil üreticilerinin $\% 87.1^{\prime} \mathrm{i}$ uygulamayanların ise \% 93.5'i kimyasal ilaçlarla mücadele hakkında teknik bilgi desteği aldıklarını ifade etmişlerdir.

Elma yetiştiriciliği yapan üreticiler arasında B/BT mücadele uygulayan grupta yer alanlar üretim sürecinde hastalık ve zararlılarla mücadele amaçlı olarak ortalama $22.4 \mathrm{kez}$, uygulamayan grupta yer alanlar ise $22.8 \mathrm{kez}$ ilaç kullandığını ifade etmiştir. B/BT mücadele uygulayan ve uygulamayan elma üreticilerinden oluşan iki grubun kimyasal ilaçlama sayısı ortalamaları arasında anlamlı düzeyde bir farklılık ( $>0.05)$ yoktur (Çizelge 5). Elmada kaliteyi etkileyen en önemli unsurların başında karaleke hastalığının geldiği, Isparta yöresinde ticari anlamda yetiştiricilik yapan üreticilerin hastalığın meyveye bulaşmasını önlemek için hiçbir ilaç ve ilaçlama masrafindan kaçınmadıkları, bir yılda karalekeye karşı ortalama 13 defa ilaçlama yapıldığ bildirilmiştir (Boyraz ve ark, 2005). Karamürsel ve ark. (2004) tarafindan Eğirdir ilçesinde yapılan bir araştırmada da yörede elma yetiştiriciliğinde görülen en yaygın hastalığın karaleke, en yaygın zararlıların ise iç kurdu ve kırmızı örümcek olduğu ifade edilmiştir. Görüldüğü gibi hastalık ve zararlılarla mücadelenin birlikte yürütülüyor olması ve kara leke hastalığının tahripkar etkisi nedeniyle yoğun mücadele gerekliliği, her iki grup arasında ilaçlama sayısının aynı kalmasını nedeni olarak yorumlanabilir. Isparta ili elma üretim alanlarında yürütülen bir başka çalışmada ise işletmelerde fazla ilaç kullanımının, uygulanan dozun ve ilaçlama sayısının fazla olması ile her ilaçlamada birden fazla ilacın karıştırılarak uygulanmasından kaynaklandığ ifade edilmiştir (Demircan ve Yllmaz, 2005). B/BT mücadele uygulayan üreticilerin \% 69.4'ü uygulamayanların ise \% 75.0'i kimyasal ilaçlarla mücadelede teknik destek aldıklarını ifade etmişlerdir.

Üreticilerin hastalık ve zararlılarla mücadele sırasında kullandıkları kimyasal ilaçlar ve kimyasal mücadele hakkında teknik destek kaynakları ağırlıklı olarak bu kimyasalların satışını yapan ilaç bayileridir. B/BT mücadele uygulayan üreticilerin $\%$ 63.9 'u, uygulamayanların \% 66.7'si, tüm üreticilerin de \% 65.3'ü için bilgi kaynağı ilaç ve gübre satışı yapan bayilerdir. Karataş ve Alaoğlu (2011) tarafından Manisa'da yürütülen çalışmada da üreticilerin \% 68.0'i ilaç seçiminde ilaç bayilerinden tavsiye aldıklarını bildirmişlerdir. Antalya ilinde yürütülen bir araştırmada ise üreticilerin \% 30.5 'i ilaç bayilerinin önerilerine, \% 28.0'i hastalık ve zararlının fiilen görülmesine, \% 25.6'sı özel danışmanın önerilerine, \% 15.9'u ise Tarım İl Müdürlügünde çalışan görevlilerin önerilerine göre kimyasal ilaçlamaya karar verdiklerini ifade etmişlerdir (Kutlar ve Ceylan, 2008).

\section{Biyolojik/biyoteknik mücadele materyali kullanmama nedeni}

Kılınçer ve ark. (2010) yapmış oldukları çalışmada biyolojik mücadele uygulamalarının son derece sinırlı ve bireysel uygulamalar olarak kaldığını ifade etmektedir. Karaturhan ve ark. (2005)' na göre; üreticiler alışkanlıklarını bırakamamaları, entegre ilaçlarının pahalı olmasından kaynaklanan ürün kaybetme korkusu, ilaç ve gübre bayilerinin etkisinde kalmaları, diğer üreticilerden etkilenmeleri, entegre ürün ve girdilerin destek kapsamında olmaması, kültürel önlemlerin zorluğu, tarım teşkilatına güvensizlik, entegre mücadele uygulayan bazı üreticilerin diğer üreticilere bilgi aktarmamaları ve benzeri gerekçelerle entegre mücadele uygulamalarına isteksiz kalmaktadırlar.

Aile işletmeciliğinin sağladığı avantajlar kullanılarak çevre dostu tarımın geliştirilebileceği, bunun için modern girdilerin kullanımını azaltmak yerine, bunları kontrol etmek ve yanlış kullanımını önlenmek gerektiği, çevre dostu yöntemlerle üretilen ürünlerin desteklenmesinin önemi Karaer ve Gürlük (2003) tarafından bildirilmiştir.

B/BT mücadele uygulaması yapmayan üreticilere, destekleme ödemesi olmasına rağmen hastalık ve zararlılara karşı mücadelede neden B/BT mücadele materyali kullanmadıkları sorulmuştur (Çizelge 6).

Çizelgeden de görüldüğü gibi, üreticilerin \% 32.4'ü B/BT mücadele uygulamasının yüksek maliyetli olduğunu, \% 19.4'ü B/BT mücadele materyallerinin zamanında ve yeterli miktarda temin edilemediğini, $\%$ 15.7'si bu destekleme modelinden habersiz olduğunu, \% 13.9'u B/BT mücadele uygulamasinda verimin düşük olduğunu, \% 12.9'u B/BT mücadele uygulamasının etkili olmadığını, \% 9.2'si komşu bahçelerde uygulanmadığ kullanmasının anlamlı olmadığını ifade etmişlerdir. Elde edilen sonuçlar bu çevre dostu yöntemleri kullanmaktan kaçınılmasına neden olan çok sayıda etken olduğunu ortaya koymaktadır. 
Çizelge 6. B/BT mücadele materyallerini kullanmama nedeni

Table 6. Reason for not using B / BT control materials

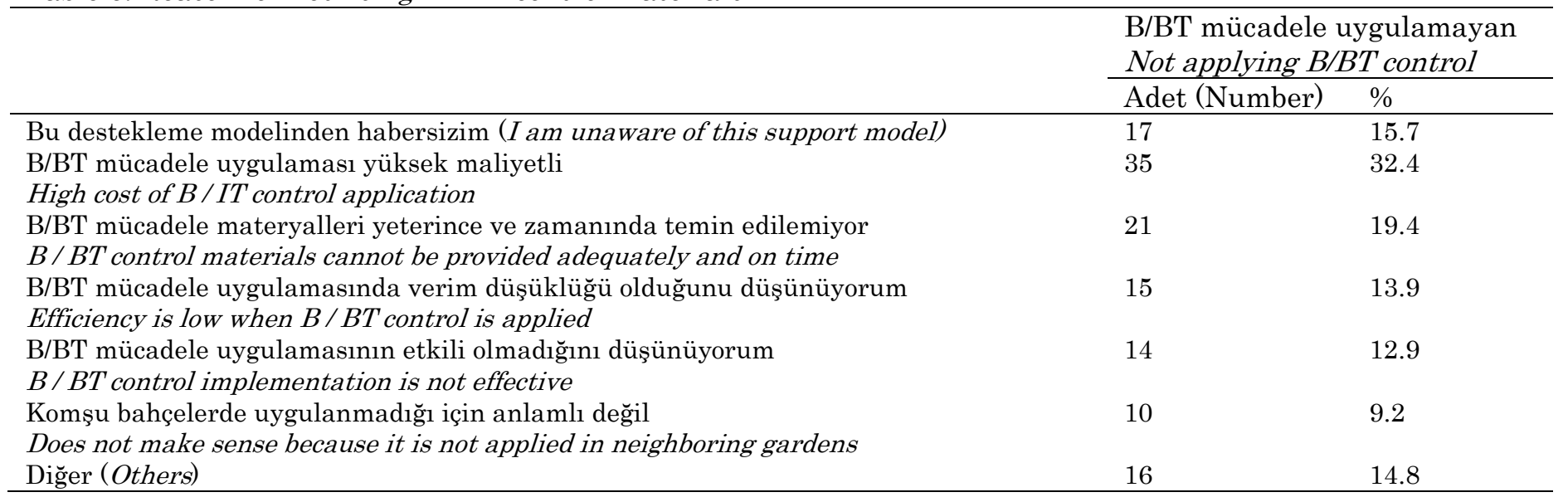

Çiftçilerin çevre duyarlılıklarının belirlenmesi

Üreticilerin Yeni Çevresel Paradigma Ölçeğinde yer alan ifadelere vermiş oldukları cevaplara bağlı olarak saptanan çevresel tutumları Çizelge 7'de verilmiştir. Buna göre araştırma kapsamında görüşülen çiftçilerin çevre tutumu ortalama 3.58 olarak belirlenmiştir. Günden ve Miran (2008) tarafindan İzmir İli Torbalı İlçesinde yapılan çalışmada ise yörede bulunan çiftçilerin çevre tutumunun ortalama 3.62 olarak belirlendiği, buna göre yöre çiftçilerinin doğal çevreye duyarlılığının yaklaşık orta derecede olduğu ifade edilmiştir. Kutlar (2016) tarafından Antalya İli Merkez İlçesinde "Entegre Mücadele Araştırma, Uygulama ve Eğitim" projesine katılan ve katılmayan üreticilerle yapılan bir çalışmada, üretim sırasında aşırı ve yanlış kimyasal ilaç kullanımının çevreye olumsuz etkileri olacağına dair görüşe, eğitim projesine katılan üreticilerin \% 26.8'i, katılmayan üreticilerin ise \% 12.2'si olumlu görüş bildirmiştir. Kızılaslan ve Kızılaslan (2005) tarafindan, çiftçilerin tarımsal ilaç kullanıp kullanmadıkları, nasıl karar verdikleri ve dikkat ettikleri konuların araştırıldığı çalışmanın sonuçlarına göre tarımsal ilaç kullanan çiftçilerin \% 50'sinin orta, \% 27.8'inin yüksek , \%22.2'sinin düşük çevre bilinç düzeyine sahip olduğu bildirilmiştir. Aynı çalışmaya göre ilaç satın alırken çevre ve insan sağllğına zararlılık düzeyini sorgulayan çiftçilerin oranı sadece $\% 5.6$ 'dır.

B/BT mücadele yöntemini uygulayan ve uygulamayan üreticilerin çevresel paradigma ölçeği puanlarını kıyaslamak için bağımsız örneklemler $t$ testi yürütülmüştür. Yapılan testin sonuçlarına göre B/BT mücadele yapan üreticiler (Ort: 53.68, Std. Sp:5.43) ve B/BT mücadele yapmayan üreticiler (Ort: 53.70 , Std. Sp:5.57) arasında anlamlı bir fark yoktur. Çevre duyarlılığının her iki grupta da eşit ve orta düzeyde olduğu sonucu, B/BT mücadele gibi çevre dostu yöntemlere her iki gruptaki üreticilerin de ilgi gösterebileceğini düşündürmektedir. Bir grubun uygulaması ve diğer grubun uygulamamasının arkasındaki gerekçeler olarak, çiftçilerin bu yöntemler hakkında yeterli bilgi sahibi olmaması, yöntemlerin etkinliği hakkında ikna olmadığından ürününü riske sokmak istememesi ve $\mathrm{B} / \mathrm{BT}$ mücadele materyalleri ile birlikte kullanılabilen kimyasalların yüksek fiyatlı oluşundan kaynaklanan maliyet artışları sıralanabilir. $\mathrm{Bu}$ gerekçelere istinaden yöntemler hakkında teknik bilgi veren yayım faaliyetlerinin artırılmasınin ve yöntemlerin destekleme kapsamında kalmaya devam etmesinin yararlı olacağı düşünülmektedir.

\section{SONUÇ}

Araştırma sonuçlarına göre; örtü altı sebze yetiştiriciliğinde üreticilerin B/BT mücadele uygulamalarını benimsemelerinde uygulamalarm sağladığı avantajlar ön plana çıkmıştır. Örtü altı sebze yetiştiriciliği faaliyeti çoğunlukla küçük aile işletmeleri ölçeğinde yürütüldüğü ve yoğun işgücü kullanımı gerektiğinden uygulama kolaylığı sağlayan B/BT yöntemlerine ilgi giderek artmaktadır. Turunçgil yetiştiriciliğinde ise birbirine komşu parsellerin tümünde uygulama yapılmadığından çok başarılı sonuçlar alınamayacağı görüşü yaygındır.

B/BT mücadele yöntemlerini uygulayan üreticilerin öncelikli olarak insan ve çevre sağllğını düşündükleri için bu yöntemleri benimsedikleri anlaşılmaktadır. Fakat bunun yanında B/BT mücadele materyallerinin yüksek maliyetli oluşu görüşü bu üretici grubu arasında da yaygındır. B/BT mücadele uygulamayan üreticiler ise B/BT mücadele uygulamasının yüksek maliyetli oluşunu, biyolojik mücadele materyallerinin zamanında ve yeterli miktarda temin edilememesini, destekleme ödemesinden habersiz olduklarını uygulama yapmamalarının başlıca gerekçeleri olarak ifade etmişlerdir. Çevresel tutum ve çevreye olan duyarlılık düzeyleri bakımından karşılaştırıldığında iki üretici grubu arasında istatistiksel olarak anlamlı bir farklılık bulunmamış olup çevre duyarlılıkları orta derecede olarak ifade edilebilir. 
1. Dünyanın barındırabileceği insan sayısı üst sınırına yaklaşıyoruz

1. We are approaching the limit of the number of people the earth can support.

2. Insanların doğayı ihtiyaçlarına uygun şekilde düzenleme hakkı vardır

2. Humans have the right to modify the natural environment to suit their needs.

3. İnsanlar doğa ile ters düştüğunde genellikle feci sonuçlar ortaya çıkar

3. When humans interfere with nature, it often produces disastrous consequences.

4. İnsan aklı bir şekilde çevre sorunlarının da üstesinden gelecektir

4. Human ingenuity will insure that we will not make the earth unlivable

5. İnsanlar doğayı ciddi şekilde istismar etmektedir

5. Humans are severely abusing the environment.

6. Eğer nasıl geliştirebileceğimizi bilebilirsek dünyada bol miktarda doğal kaynak mevcuttur

6. The earth has plenty of natural resources if we learn how to develop them

7. Insanlar gibi bitkiler ve hayvanların da bu dünyada var olma hakları mevcuttur

7. Plants and animals have as much right as humans to exist.

8. Doğanın dengesi modern sanayileşmiş ulusların etkileriyle başa çıkabilecek kadar güçlüdür

8. The balance of nature is strong enough to cope with the impacts of modern industrial nations.

9. Özel yeteneklerimize rağmen biz insanlar halen doğanın kanunlarına tabiyizdir.

9. Despite our special abilities humans are still subject to the laws of nature.

\begin{tabular}{|c|c|}
\hline Ortalama & \\
\hline $\begin{array}{l}\mathrm{B} / \mathrm{BT} \\
\text { mücadele } \\
\text { uygulayan } \\
\text { Applying } \\
\text { B/BT control }\end{array}$ & $\begin{array}{l}\text { B/BT mücadele } \\
\text { uygulamayan } \\
\text { Not applying } \\
\text { B/BT control }\end{array}$ \\
\hline 3.44 & 3.65 \\
\hline 2.55 & 2.72 \\
\hline 4.44 & 4.46 \\
\hline 3.32 & 3.29 \\
\hline 4.54 & 4.40 \\
\hline
\end{tabular}

10. Insanların karşı karşıya olduğu şu meşhur ekolojik kriz çok fazla abartılmaktadır

10. The so-called "ecological crisis" facing human kind has been greatly exaggerated.

11. Dünya çok sınırlı sayıda odası ve kaynakları olan bir uzay gemisine benzemektedir

11. The earth is like a spaceship with very limited room and resources.

12. İnsanlar doğanın kendileri dışında kalan kısmına hükmetmek üzere yaratılmışlardır

12. Humans were meant to rule over the rest of nature.

13. Doğanın dengesi çok kırılgandır ve kolayca bozulabilir

13. The balance of nature is very delicate and easily upset.

14. İnsanlar doğayı kontrol edebilmek için onun nasıl işlediğine ilişkin yeterli bilgiyi er geç öğreneceklerdir.

14. Humans will eventually learn enough about how nature works to be able to control it.

15. Ĕ̆ger işler şu an oldukları gibi devam ederse yakında büyük bir ekolojik felaketle karşılaşacağ

15. If things continue on their present course, we will soon experience a major ecological catastrophe.

$\begin{array}{llllll}\text { Çevresel } & \text { Uygulama tipi } & \text { Toplam } & \text { Ort } & \text { Std.Sp } & \text { t- testi } \\ \text { paradigma } & \text { Type of applying } & \text { Total } & \text { Mean } & S D & \text { t-test } \\ \begin{array}{l}\text { ölçeği toplam } \\ \text { puanı }\end{array} & \begin{array}{l}\text { B/BT mücadele uygulayan } \\ \text { Applying B/BT control }\end{array} & 53.68 & 3.58 & 5.429 & \end{array}$

Ecological

paradigm $\quad \mathrm{B} / \mathrm{BT}$ mücadele uygulamayan

scale total Not applying B/BT control

53.70

$3.58 \quad 5.572$


Gerek insan sağlığı ve doğal denge açısından, gerekse zararlılarda kimyasallara karşı direnç oluşumu ve yoğun kimyasal kullanımının önlenmesi amacıyla üreticilerin B/BT mücadele uygulamasına teşviki son derece önemlidir. Bu yöntemler hakkında üreticilere teknik bilgi veren yayım faaliyetlerinin artırılması kısa vadede yapılabileceklerin başında gelmektedir. $\mathrm{Bu}$ yöntemlerin yaygınlaştırılması için üreticiler bu mücadele yöntemleri hakkında bilgilendirilmeye ve maddi olarak desteklenmeye devam edilmeli, bunun yanında tüketicilere de bu yöntemlerle üretilmiş ürünleri tüketme eğilimi yaratacak bilgilendirme çalışmaları yapılmalıdır. B/BT mücadele yöntemlerinin uygulanmasında, gerek üreticilerin eksik bilgi ve ihmallerinden ve gerekse aparat ve canlı materyalleri pazarlayan fïmaların satış sonrası ziyaretlerinin yetersizliğinden kaynaklanan aksaklıkların giderilmesi, uygulamaların başarısına olan inancı güçlendirecektir. Büyük bölümü ithal edilen B/BT mücadele materyallerinin yüksek maliyetleri üreticileri bu uygulamalardan uzaklaştırmakta, yöntemlerin uygulanması sırasında yaşanan gecikmelerin de ithalat sürecinden kaynaklandığı anlaşılmaktadır. $\mathrm{Bu}$ nedenle B/BT mücadele uygulamalarının yaygınlaşmasına katkı sağlayacak yerli B/BT materyallerinin üretimi için gerekli alt yapı ve girişimlerin desteklenmesi hususu yetkililer tarafindan orta ve uzun vadeli hedefler arasina alınmalıdır.

\section{TEŞEKKÜR}

$\mathrm{Bu}$ çalışma, 2017-2018 yıllarında Tarımsal Araştırmalar ve Politikalar Genel Müdürlüğü'nün fon desteği ile yürütülen bir projeden elde edilen verilerle hazırlanmıştır.

\section{Çıkar Çatışması Beyanı}

Makale yazarları aralarında herhangi bir çıkar çatışması olmadı̆̆ını beyan ederler.

\section{Araştırmacıların Katkı Oranı Beyan Özeti}

Yazarlar makaleye eşit oranda katkı sağlamış olduklarını beyan ederler.

\section{KAYNAKLAR}

Anonim 2014 a. Kalkınma Bakanlığı 10. Kalkınma Planı Bitkisel Üretim ÖİK Raporu. s:26-28

Anonim 2014 b. Bölge Planı 2014-2023. TR Düzey 2 Bölgesi. Batı Akdeniz Kalkınma Ajansı, s.61, Antalya.

Anonim 2015. Ülkemizde Zirai Mücadele Girdilerinin Değerlendirilmesi,

https://arastirma.tarimorman.gov.tr/zmmae/Belgel er/SolMenu/Yayınlar/ÜlkemizdeZiraiMücadeleGir dilerininDeğerlendirilmesi.pdf (Erişim tarihi: 01.02.2019)
Ateş A, Sayın C 2008. Antalya İlinde Örtüaltı Yetiştiriciliğinde Özel Tarımsal Danışmanlık Hizmetleri Üzerine Bir Araştırma. Akdeniz Üniversitesi Ziraat Fakültesi Dergisi, 21(2): 251263.

Birişik N, Altındişli Ö, Kılıç T, Özsemerci F, Turanlı T, Kaplan C, Tolga F, Kovancı O.B, Pehlevan B, Turanlı D, Işık F, Yılmaz E 2013. Teoriden Pratiğe Biyoteknik Mücadele. Gida ve Kontrol Genel Müdürlüğü. $189 \mathrm{~s}$.

Boyraz N, Kaymak S, Yiğit F 2005. Eğirdir İlçesi Elma Üreticilerinin Kimyasal Savaşım Uygulamalarının Genel Değerlendirilmesi. S.Ü Ziraat Fakültesi Dergisi, 19(36): 37-51.

Boz Ö, Erol T, Benlioğlu S, Öncüer C 1998. Aydın İli Zirai Mücadele Uygulamalarının Sosyo-Ekonomik Yönden Değerlendirilmesi. Türk Entomoloji Dergisi, 22(2): 123-136.

Bulut E, Göçmen H 2000. Pests and Their Natural Enemies on Greenhouse Vegetables in Antalya. Bulletin OILB Srop, 23(1): 33-37.

Cordano M, Welcomer SA, Scherer RF 2003. An Analysis of The Predicive Validity of The New Ecological Paradigm Scale. The Journal of Environmental Education 34, 22-28.

Çelik A, Karakaya E 2017. Bingöl İli Adaklı İlçesi Elma Üreticilerinin Tarımsal İlaç Kullanımında Bilgi Tutum ve Davranışlarının Değerlendirilmesi ve Ekonomik Analizi. Türk Tarım ve Doğa Bilimleri Dergisi, 4(2): 119-129.

Çiçek A, Erkan O 1996. Tarım Ekonomisinde Araştırma ve Örnekleme Yöntemleri. Gaziosmanpaşa Üniversitesi, Ziraat Fakültesi Yayınları No: 12, Ders Notları Serisi No: 6, Tokat

Delen N, Tosun N, Toros S, Öztürk S, Yücel A, Çalı S 1995. Tarım İlaçları Kullanımı ve Üretimi. Türkiye Ziraat Mühendisliği 4.Teknik Kongresi, TC Ziraat Bankası Kültür Yayınları No:26, 10151028, 9-13 Ocak, Ankara.

Delen N, Durmuşoğlu E, Güncan A, Güngör N, Turgut C, Burçak A 2005. Türkiye'de Pestisit Kullanımı, Kalıntı ve Organizmalarda Duyarlılık Azalışı Sorunları. Türkiye Ziraat Mühendisliği VI. Teknik Kongre, 629-648, 3-7 Ocak, Ankara.

Demircan V, Yllmaz H 2005. Isparta İli Elma Üretiminde Tarımsal İlaç Kullanımının Çevresel Duyarlılık ve Ekonomik Açıdan Analizi. Ekoloji, 14(57):15-25.

Dunlap RE, Van Liere KD, Merting AG, Jones RE 2000. Measuring Endorsement of The New Ecological Paradigm: A Revised Scale. Journal of Social Issues 56, 425-442.

Gül M, Akpınar MG, Demircan V, Yılmaz H, Bal T, Arıcı ŞE, Polat M, Şan B, Eraslan F, Örmeci Kart MÇ, Gürbüz D, Yılmaz ŞG 2014. Zirai İlaç Bayilerinin Yapısı ve Entegre Mücadele Konusundaki Tutum ve Davranışları, Süleyman 
Demirel Üniversitesi Ziraat Fakültesi Dergisi 9 (1):11-25, 2014.

Günden C, Miran B 2008. Yeni Çevresel Paradigma Ölçeğiyle Çiftçilerin Çevre Tutumunun Belirlenmesi: İzmir İli Torbalı İlçesi Örneği. Ekoloji 18, 69, 41-50.

Karabaş S, Gürler Z 2011. Organik Tarım ve Konvansiyonel Tarım Yapan İşletmelerin Karşılaştırmalı Analizi. KMÜ Sosyal ve Ekonomik Araştırmalar Dergisi, 13(21): 75-84.

Karabat S, Atış E 2012. Manisa İli Bağ Alanlarında Kullanılan Tarımsal İlaçların Gıda Güvenliğine Etkisinin Koşullu Değerleme Yöntemiyle Analizi. Ege Üniv. Ziraat Fak. Derg., 2012, 49 (1): 17-25

Karaer F, Gürlük S 2003. Gelişmekte Olan Ülkelerde Tarım-Çevre-Ekonomi Etkileşimi. Doğuş Üniversitesi Dergisi, 4 (2): 197-206

Karamürsel D, Öztürk FP, Öztürk G, Kaymak S, Eren İ, Akgül H 2004. Eğirdir Yöresi Elma Yetiştiriciliğinin Durumu ve Sorunlarının Belirlenmesi ile Ekonomik Yönden Değerlendirilmesi. Türkiye VI. Tarım Ekonomisi Kongresi, 225-231, 16-18 Eylül, Tokat.

Karataş E, Alaoğlu Ö 2011. Manisa İlinde Üreticilerin Bitki Koruma Uygulamaları. Ege Üniversitesi Ziraat Fakültesi Dergisi, 48 (3): 183189

Karaturhan B., Boyacı M, Yaşarakıncı N 2005. Ege Bölgesinde Entegre MücadeleninYayıminda Karşılaşılan Sorunlar:Örtü Altı Sebze Yetiştiriciliği Örneği, Ege Üniversitesi Ziraat Fakültesi Dergisi, 42(2):155-166.

Kılınçer N, Yiğit A, Kazak C, Er MK, Kurtuluş A, Uygun N 2010. Teoriden Pratiğe Zararlılarla Biyolojik Mücadele, Türkiye Biyolojik Mücadele Dergisi, 1 (1): 15-60.

Kızılaslan H, Kızılaslan N 2005. Çevre Konularında Kırsal Halkın Bilinç Düzeyi ve Davranışları (Tokat İli Artova İlçesi Örneği). ZKÜ Sosyal Bilimler Dergisi, 1(1)67-89.

Kutlar İ 2016. Örtüaltı Sebze Yetiştiriciliğinde Entegre Mücadele Yönteminin Gıda Güvenliği Açısından Önemi: Antalya İli Örneği. XII. Ulusal Tarım Ekonomisi Kongresi, Cilt:3, 2001-2010, 2527 Mayıs, Isparta.

Kutlar İ, Ceylan C 2008. Antalya İli Merkez İlçesinde Entegre Mücadele Yönteminin Yayılması ve Benimsenmesi. Bahçe 37 (1): 25 - 33.
Özkan A, Akıncı AR, Soysal A 1991. Antalya İlinde Çiftçilerce Zararlı Mücadelesinin Kavranması ve Uygulamaları Konulu Survey. Derim, 8(2): 56-75.

Satar S, Karacaoğlu M, Satar G 2012.Turunçgil Bahçelerinde Kullanılan Bazı İlaçların Yaprakbiti Parazitoitlerinden Lysiphlebus confusus Tremlay \& Eady, Lysiphlebus fabarum(Marshall) ve Lysiphlebus testaceipes (Cresson) (Hymenoptera: Braconidae)'e Karşı Etkileri. Türk Entomoloji Dergisi, 36(1): 83-92.

Sayın B, Çelikyurt MA, Kuzgun M, Aydın B 2015. Antalya İlinde Örtüaltı Yetiştiriciliği Yapan Üreticilerin İyi Tarım Uygulamalarına Yaklaşımı. Derim, 32(2):171-186.

Tanrıvermiş H 2000. Orta Sakarya Havzasında Domates Üretiminde Tarımsal İlaç Kullanımının Analizi. Tarımsal Ekonomi Araştırma Enstitüsü, Yayın No: 42, Ankara.

Tiryaki O, Canhilal R, Horuz S 2010. Tarım İlaçları Kullanımı ve Riskleri. Erciyes Üniversitesi Fen Bilimleri Enstitüsü Dergisi 26(2): 154-169.

Topuz E 2005. Tarımsal Zararlılarla Mücadelede Kimyasal Pestisitlere Alternatif Bazı Yöntemler. Derim, 22 (2), 53-59.

Tüzel Y, Öztekin GB, Karaman İ 2010. Serik İlçesindeki Modern ve Geleneksel Sera İşletmelerinin Üretici Özellikleri, Sera Yapısı ve Sebze Üretim Teknikleri Bakımından Karşılaştırılması, Ege Üniversitesi Ziraat Fakültesi Dergisi, 47 (3): 223-230

Yamane T 1967. Elementery Sampling Theory Prentice. Hall Inc, Englewood Cliffs, 405 p., N.J., USA

Yanar D, Yanar Y, Erdal H, Erdal G, Poyraz E 2018. Antalya İlinde Örtü Altı Yetiştiriciliğinde Karşılaşılan Bitki Koruma Sorunları ve Üretici Bilinç Düzeyi. Gaziosmanpaşa Bilimsel Araştırma Dergisi, 7(3) : 38-48

Yıldırım Ç, Başer U, Türkten H, Soytopak H, Ceyhan V 2016. Antalya İli Kaş İlçesinde Örtüaltı Yetiştiriciliğinde Biyolojik Mücadele Yapan ve Yapmayan İşletmelerin Karşılaştırmalı Analizi. XII. Ulusal Tarım Ekonomisi Kongresi, 1. Cilt, 147-156, 25-27 Mayıs, Isparta.

Zeren O, Erem G 1999. İçel İlinde Turunçgil ve Sebzelerde Kullanılan Pestisitler. Türkiye Tarım Kredi Kooperatifleri Merkez Birliği Türk-Koop Ekin, 7, 63-65, Ankara. 